\title{
THE USE OF A RANGE OF PERFORMANCE MANAGEMENT PROCESSES RECOMMENDED FOR THREE GROUP OF STAFF AT DIFFERENT ORGANIZATION
}

\author{
Arief Fahmie \\ Islamic Universily of Indonesia
}

\begin{abstract}
Inti dari manajemen kinerja adalah memberikan panduan agar kinerja individu dan kelompok dapat diarahkan, dimonitor, dimotivesi, dan diberi kompensasi. Setiap perusehaan afau organisasi mempunyai kebutuhan, lingkungan, dan pendekatan yang unik dalam strategi manajemen sumber daya manusia, termasuk proses manajemen kinerja. Oleh karena itu. masalah utama implementasi manajemen kineja adalah menentukan proses, metode, dan teknis pelaksanaan yang terbaik untuk meningkatkan kinerja di sebuah perusahaan atau organisasi. Perancangan manajemen kinerja yang berbeda-beda dapaf dicontohkan pada studi kasus dari 3 macam staf di orgenisasi yeng berbeda yaitu sfaf penjualan df perusehaen mesin pembersih lantai, peneliti df laboratorium perusehaan farmasi, serta dosen-dosen of universitas. Contoh-contoh tersebut menggemberken bahwa kondisi tiap organisasi mempengaruhi metode ferbaik yang dipilh dalam perancangan manajemen kinerja. Selanjufnya, orgenisasi-organisasi yang mengimpiementasikan manajemen kineja juga pertu menitikberatkan pada pengembangan budaya pembelajar. Di samping itu, agar pendekatan yang dipilih menjadi bermakna maka prinsp-prinsip elis periu diterapkan dalam proses manajernen kiner,a.
\end{abstract}

Kata Kunci: Proses manajemen kinerja

\section{Introduction}

Chartered Institute of Personnel and Development (C|PD) survey showed that 26 per cent respondents thought performance management was bureaucratic and timeconsuming; while 22 per cent disagreed that performance management motivated individuals (CIPD, 2005). However, many organisations have priorities to implement the people strategy and $b$ use performance management to drive business performance (Personnel Today, 2005). As IRS Survey (Armstrong and Baron, 1998) find, there are various reasons for introducing performance management such as to improve performance and to identify training needs, to improve customer service, or to change the culture. In addition. Personnel Today in partnership with PeopleSoft survey found the vast majority of respondents ( 86 per cent) say the introduction of a performance management system has had a positive impact on their organisation (Personnel Today, 2004). The problem of using performance management therefore is to determine what process, tools, delivery mechanism will improve performance in the organisation, and which are best avoided (Armstrong and Baron, 2005).

The use of a range of performance management processes recommended for sales representatives for a vacuum cleaner company, research scientists in a research laboratory within a large pharmaceutical firm, and lecturers at a large university are presented to explain various implementations of performance management at different organisations. Firstly, the first section critically reviews the 
concepts relating to performance management and performance appraisals. The second section describes case studies of three different organisations: a vacuum cleaner company, a research laboratory within a pharmaceutical firm, and a large university. Thirdly, the findings of investigation will be presented, followed by critical discussion and analysis of them. Finally, conclusions and recommendations for follow-up action are presented in the last section.

\section{Concepts of Performance Management and Performance Appraisal}

Clark (1999: 126) indicates, "There is no single universally accepted model of performance management in use". However, Armstrong and Baron (1998), Hendry et al. (1997), and Thorrington et al (1998) mention that the essence of performance management is establishing a framework in which performance by individuals and teams can be directed, monitored, motivated, and rewarded; and represents a more holistic view of performance. Furthermore, performance appraisal is centre of the process, but it is integrated with performance planning (connecting an individual and departmental objectives to organisation objectives) to ensure that employee effort is focussed to organisational priorities. It also supports for performance delivery (via developmenf plans, coaching and ongoing review) to facilitate employee effort to be successful, and that performance is assessed and successful performance rewarded and reinforced.

Description of performance management process is explained by a continuous cycle based on Deming's model for continuous quality management (Armstrong and Baron, 1998). The variations of models are produced by Armstrong and Baron (1998), Beardwell and Holden (2001), Clark (1998), and Torrington et al (2004). h practice, some organisations develop such models, for instance The University of Virginia (University of Virginia, 2005), Standard Chartered Bank (Armstrong and
Baron, 2005). CIPD survey (2005) explains the practice of performance management still largely revolves around objective setting and appraisal. It also illustrates that a wide range of tools are used $b$ managed performance that are more likely to be linked with other aspects of people management, such as talent management, succession planning, development or career management. Both theoretical and practical models, hence, consist of same basic elements that founded on Deming's model: plan, act, monitor, and review (Armstrong and Baron, 1998).

Conversely, Brown (2002) states many business leaders do not believe performance management has to be an important part of the strategic plan. They think of it as just another HR initiative rather than a necessary component of business plan implementation. It is essential consequently to consider both theorefical and practical issues when implementing performance management. Each organisation should design the performance management process strategically based on the circumstances and needs of the organisation, customer, and employees since no one right way of practicing performance management (Blyth, 2005; Rodgers, 2005). Otherwise. performance management maybe considered as old wine, new label, and new flavour (Thornhill et al, 1998).

Armstrong and Baron (2005) then summarize the main issues concerning performance management idenfified by writers and researchers as well as possible responses by practitioners. Firstly, the most important issue is line management commitment and capability. This may be achieved by some approaches such as providing systematic training in the performance skills managers need to use, using competence in performance management as a key criterion in assessing manager's performance. The second issue is poorly designed performance management process. It should be planned by wellorganised process such as using the pilot testing; building personal development plans into the process. Thirdly, unitary and pluralistic frames of reference must be 
considered since top management, line managers, and employee may have different vlewpoint. This must be considered in the involvement, communication, and training programmes. Focusing performance management on financial rewards is the fourth issue. It is wrong to assume that performance management is synonymous with performance-related pay. Finally, performance management is a means of oppressive or coercive control. Therefore, a stakeholder approach recognises the diversity of interests is appropriate and which is conducted in accordance with ethical principles and the rules of procedural justice is right.

Nonetheless, there are no general issues concerning performance management and possible responses for all organisations. Every company has unique needs, circumstances, and approaches in which hurnan resource strategy, including performance managernent process, is used effectively. For example, CIPD (2005) reports that $36 \%$ respondents from non-profit organisations perceive training as key issue in performance managernent compared with only $13 \%$ of those from manufacturing and service sector. Conversely, communications of objectives is more important in manufacturing as $35 \%$ respondents from this particular industry decide that it is key issues than in non-profit organisations in which $21 \%$ the respondents have same opinion. This leads designing performance management process is case-by-case basis to achieve the high quality planning.

\section{Case Studies}

Three case studies cited from Ben Lupton, Manchester Metropolitan University, are presented to describe three groups of staff: sales representatives for a vacuum cleaner company, research scientists h a research laboratory within a large pharmaceutical firm, and lecturers at a large university. This explain what is the best way to administer performance management process depends on particular organisation contexts (Armstrong and Baron, 2005).
1. Sales representatives for a vacuum cleaner company

Each sales representative works in a local area selling vacuum cleaners. They visit householders by arrangement after they have responded to an advertisement. The strategy of the company is to provide good (but not exceptional) quality products at a reasonable (but not cheap) price and to compete on the basis of having better after sales service (prompt and effective repairs, providing a replacement when repairs are undertaken, help lines, and customers building long-term relationships with trusted sales representatives). The idea is that customers will be attracted by this and remain loyal to the company every time they need to buy a new vacuum cleaner, and recomrnend the company to other potential customers. Each locality is managed by a sales and customer service manager who is accountable for this, and who has a tearn of sales representatives working for him or her.

2 Research scientists in a research laboratory within a large pharmaceutical firm

The purpose of the laboratory is to design new products for the mass drug market. Successful new products are large profit markers for the company, and without them the company would struggle to survive. However, successful new products are difficult and time consuming to create. $95 \%$ of ideas for new products do not reach the production stage. On average, only one successful product is produced every three years. Even at this rate, they can sustain the organisation until the next new product is ready. The employees in the laboratory, around 20 , are research scientists recruited from top universities. They report to a newly appointed laboratory director, who has an MBA and is not a scientist by training. The scientists like to work independently on their ideas, and are used to flexible working style of the university environment from which they have come. Indeed, they consider themselves to be academics even though the work in the industry, and many would like to return to the university environment, though 
the high salaries in industry and are enough (just) to make them stay. Many continue to write articles for top academic journals (using work time and facilities), and like to go to academic conferences, even though this has no direst return for the company.

Moreover, the manager is concerned about the amount of time spent on this, also by the fact that the scientists come and go as they please, and the fact that they seem to spend a substantial part of their time playing chess and computer games, although the scientists normally work as individuals, they do share ideas and test each others product designs. When a new product is proposed for development, the scientist(s) who originally thought of it have their name recorded on the product proposals, but it widely recognised that almost everyone in the laboratories will have had some type of input, often one that is critical to the final design. Some scientists have not had a product proposal with their name on it for more than three years.

\section{Lecturers ata large university}

The university has three main strategic objectives, which are linked to their generation of income. The first is to provide high-quality teaching and learning experience for students. This impacts on the reputation of the university, and thus on the number of students it can attract to courses, and also on the university's government funding, which is allocated on a per capita basis. The quality of teaching and learning is assessed formally every year by the national auditors and published widely. The second objective is to design, provide, and administer a wide range of courses at affordable cost to meet the university's historical commitment to the local community, which affects the university's ability $\mathrm{t}$ build relationships with local organisations and to attract commercial and public sponsorship. The third objective is for the university to be a successful centre for research. Research is also assessed centrally (in terms of the amount and quality of academic publications), and the university's grading has a direct impact on the amount of funding received from central government. Indeed, this funding is much greater and more variable than that received for teaching. Research strategies are also published, and this affects the equality of students who attend the university and of staff who are attracted to work there. High-quality students contribute to research and attract betterresearch-focused lecturers.

Lecturers work in loosely structured non-hierarchical departments, nominally managed by a head of department, but in reality this is just the senior academic, who leads by advice and example, rather than a manager in the formal sense. Each lecturer is expected to take on teaching roles, roles in course design and administration, and to undertake research. However, the reality is that they balance these requirements pretty much as they see fit. Lecturers are attracted to work in the University for Several Reasons, even though many could earn more money in the commercial world, some by desire to teach, and some by the desire to research, and all by the flexible nature if their jobs and the freedom to 'do their own thing' without close management.

\section{Discussion}

\section{Sales representatives for a vacuum cleaner company \\ The vacuum cleaner company has set} its objectives related to the quality and price of products and level of the service that are the basis of the performance of sales representatives. The manager and sales persons based on the business objectives then define the individual and team performance objectives as well the competence required because according to Beardwell and Holden (2001) getting employees involved in the planning process will help them understand the goals of the organisation. It also makes them know what needs to be done, why it needs $t \mathrm{~b}$ be done, and how well lt should be done. To set the objectives and competence in unitary frames of reference is avoided because management, line managers, and employees may have different viewpoint (Armstrong and Baron, 2005). Performance elements and standards, moreover, should 
be specific, measurable, achievable, realistic, and time bound (SMART) (Armstrong and Baron, 1998). Through critical elements, sales representatives are held accountable as individuals and teams for work responsibilities.

Customer and service manager, and costumers in each local area then assess sales representatives' performance on both individual and team-based, once a year in particular months by using Behaviourally Anchored Rating Scales (BARS) that attempt to clearly define the scale labels and anchors used in performance ratings (Riggio, 2003). Asking for feedback from the costumers is important because costumer satisfaction, including their recommendation to other potential customers, is part of the idea of the organisational objectives. The performance appraisal for individual contributions to the team also involves assessment from colleagues as each sales representative works in teamwork basis in a particular local area, th short, the appraisal technique used is partial 360-degree method since the appraisees are the appraisee's peers, up-line managers, and customers. Other pitfall may occur because the focus of the performance management process is work teams although individual accomplishments that support the team's process are also appraised that affects reward system. Therefore, it is essential to list the key process steps taken by the team and the accomplishments needed to support each process (Castka et al., 2001). Moreover, the characteristic of area influence the performance standard, such as prospective areas will have higher target rather than less potential ones. The design of sales related performance management process should consider the need to balance greater risk with greater rewards (Bartol, 1999). Otherwise, this may lead to a poorly designed performance management process; and using the pilot testing may decrease unfairness in the performance management process.

Finally, as it is important to reward to the achievement of sales representatives, individual performance-related pay may be considered. However, this can inhibit teamwork (Armstrong, 2002). The management afterwards may use team rewards to remunerate the sales representatives' performance. Payment of base salary reflects the value of the individual's contribution to the team while bonus is a percentage of base salary. The reason is that the reward system motivates team works bo work effectively together (Bratton and Gold, 1999). This is suitable since sales representatives work in team based managed by a sales and customer service manager. Nonetheless. distinguishing what individual team members contribute could be a problem. Hence, sales representatives should be involved as members of taskforces in the design of scheme; considerations should be given to non-financial extrinsic and intrinsic rewards; development of the capacity to perform successfully in team is important (Armstrong, 2002).

2. Research scientists in a research laboratory within a large pharmaceutical firm

As a large pharmaceutical firm, the company has an organisational objective to design new products for the mass drug market. This is the basis of the performance of research scientists in the research laboratory. Both the laboratory director and research scientists then identify the department objectives, the individual performance objectives, and the essential competence. Objectives need to be clear and concise about what is to be achieved. They should be realistic and be flexible but challenging, neilher too comfortable nor dauntingly unrealistic. As Mabey et at (1999) explain, one of theories underpin performance management cycle is goal setting-theory. This theory postulates that setting goals regulates behaviour and enhances performance since the research scientist have different orientations such as they like to return to the university environment, while some scientists have not had a product proposal with their name on it for more than three years. According to goalsetting theory, the highest level of 
commitment $b$ goals is attained when individuals believe the goal is important and attainable (Mabey et al, 1999). The laboratory director and research scientists therefore discuss, agree, and record priorities and objectives, how progress will be monitored, and personal development plans will be built into the process with each of the research scientists. This may avoid from poorly designed performance management process.

Next, the laboratory director and research scientists assess research scientists' performance per annum in particular months employing graphic rating scales. Graphic rating scales method offer predetermined scales $b$ rate the employee on a number of important aspects of the job (Riggio, 2003). The employees' self ratings of performance are used in conjunction with the laboratory director's and peers' ratings. However, the basic problem is employees usually rate themselves higher than they are rated by supervisors of peers (Desster, 2005). This may become problem since the laboratory director as line manager is a newly appointed one, who has an MBA and is not a scientist by training. Therefore, each research scientist and the director should know that their appraisais might accentuate appraiser-appraisee differences. Moreover, to improve the laboratory director's capability, it may be achieved by providing training in the performance skilis including general knowledge of the production process since he or she is not a scientist by training.

The focus of the performance management process is individual performance because the result of their work is a product proposal although the research scientists share ideas and test each other product designs. However, because they are recruited form top universities but some of them have not had best performance and are used to the flexible working style inappropriately, the performance review meeting is prepared not only to discuss the achievement of performance objectives but also to identify the strengths and opportunities for improvement in coaching activities. The laboratory director should recognise the diversity of interests; otherwise the research scientist may perceive that performance management means repressive control.

Regarding with reward system, using performance-related pay is considered since i. links reward to outputs (Beardwell and Holden, 2001). The company might be concerned with rise of the number of product proposals. As it is mentioned, successful new products are difficult and time consuming $b$ create in which $95 \%$ of ideas for new products do not reach the production stage; and one successful product produced every three years can sustain the organisation until the next new product is ready. Therefore, the more product proposal is produced the more possibility new product accomplish production period. However, performancerelated pay may emphasise quantity at the expense of quality (Armstrong, 2002). The management then might use contributionrelated pay to reward the research scientists' perfarmance. Competence is used as the major component in determining salary while output is basis of deciding bonus. This is suitable since both how product proposals are achieved and the proposals themselves are important. However, it will work only if there are competence frameworks in place, if out-puts can be measured, and if there are fair and consistent methods of assessing competence and measuring output (Armstrong, 2002). The laboratory director and research scientists as a result have to develop the criteria of assessment of competencies as well as out put. Moreover, gain-sharing plans might be introduce to supplement contribution-related pay.

\section{Lecturers ata large university}

The university have three objectives that correlated with high-quality teaching and learning, a wide range of courses at affordable cost, and centre for research directing to departmental objectives. The heads of departments and the lecturers based on the organisational then define the departmental and performance objectives that are the basis of the individual performance appraisal as well the 
competence required. Again, involving lecturers makes them understanding the goals of the organisation, what needs to be done, why it needs to be done, and how well it: should be done (Beardwell and Holden, 2001). This is major point since they balance between roles in teaching, course design and administration, and research pretty much as they see fit. Moreover, as the heads of departments are just the seniors academic rather than managers in the formal sense, they may have lack of capability in performance management skills. Therefore, some approaches such as providing systematic training in the performance skills they need to use or using competence in performance management as a key criterion in assessing the heads of departmenis' performance.

The performance appraisal method is checklists that consist of a series of statements about performance in a particular job (Riggio, 2003). Upward appraisal in particular months that involves a formal input by students into the performance appraisal of their lecturers is used to assess in teaching area because students are in a good position to observe directly the behaviour of their lecturers. Performance measures identified in the research study as likely to be valid and acceptable to academic staff should be considered in appraisal system design (Simmons, 2002). Then, the heads of departments might appraise roles in course design and administration. Moreover, peer review is needed in appraising performance in research and roles in course design and administration; and self-appraisal is used to assess performance in teaching, course design and administration, and research. Therefore, the process employs the portial 360-degree feedback; however, since the appraisal evaluation process remains very subjective, they management should consider types of such systematic problems, including leniency or severity errors, halo effects, recency effects, causal attribution errors, and personal biases (Riggio, 2003). Moreover, the university may use the result of appraisal system as data for balanced score system for the management to give them a fast but comprehensive view of the business since the organisational objectives are related to customer, internal, innovation and learning, financial perspective (Armstrong and Baron, 1998).

Although they may share ideas or work in team when conducting research project, the focus of the performance management process is individual performance in teaching. course design and administration, and research. This may give lecturers the primary responsibility to identify aspects of their roles in which development is possible and desirable. This soft approach of HRM is important since performance appraisal to university lecturers has similarly been interpreted as a means to increase managerial control over diverse occupational groups formerly immune from these processes (Bach, 2000).

A team-based reward is one of possible payment method because some jobs are either team or individual based such as conducting research. However, skillbased pay is more appropriate as it provides flexibility so that employees can be transferred between different parts of the operations, thus increasing the ability of the company to vary production or services it provides in response to changes in customer demand or business peaks or troughs (Armstrong. 2002). This is suitable for the lecturers who have responsibility in different fields, and as a result, improves the capability of the company to achieve the organisational objectives. Nevertheless, a recognition of the difficulties of designing, implementing, and operating such system may well be discouraging many organisations (Kessler, 2000). As a result, identification the correct skill, establishment of methods of verifying the skill acquired, and arrangement of training are important (Armstrong, 2002).

\section{Recommendations}

The diagram below shows the planning of performance management processes and the sequence of events expected. 


\section{Figure 1.}

The Model of Perf ormance Management Process

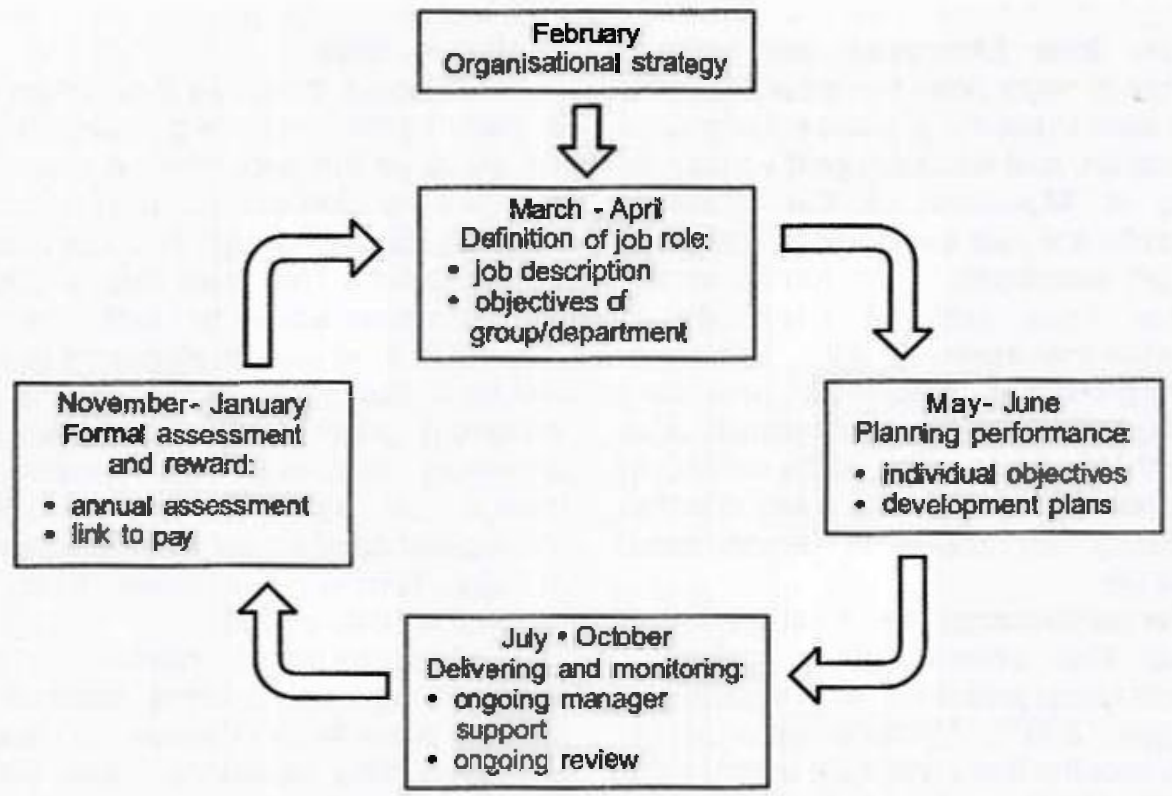

Source: modified from Torrington et al. (2004:263)

What is the best way to administer perfomance management process depends on particular organisation contexts (Armstrong and Baron, 2005). Performance management process are geared to ensure that each employee within the organisation, based on previously conducted job analyses, is performing the tasks intended at the expected level to support the strategic business objectives of the organisation. Effective performance management entails a process where each employee is fully aware of his or her role in the organisation, the type of output expected, the development plans, and how the output will be measured and rewarded.

In general, all organisations follow similar pattern based on the modified Tortington et al's model of performance management process although they also have different approaches in particular steps described below, especially in performance appraisal methods and reward system. 
Figure 2

The Different Approaches in Performance Management for Three Different Companies

\begin{tabular}{|l|l|l|l|}
\hline & $\begin{array}{l}\text { The Vacuurn Cleaner } \\
\text { Company }\end{array}$ & $\begin{array}{l}\text { The Research } \\
\text { Laboratory within a } \\
\text { Pharmaceutical Firm }\end{array}$ & The Large University \\
\hline $\begin{array}{l}\text { Performance } \\
\text { appraisal } \\
\text { methods }\end{array}$ & $\begin{array}{l}\text { Behaviourally } \\
\text { Anchored Rating } \\
\text { Scales (BARS) by } \\
\text { costumers, customer } \\
\text { and service } \\
\text { managers, and } \\
\text { colleagues }\end{array}$ & $\begin{array}{l}\text { Graphic rating scales } \\
\text { by employees, the } \\
\text { laboratory director, } \\
\text { and peers }\end{array}$ & $\begin{array}{l}\text { Checklists by heads of } \\
\text { departments, } \\
\text { students, and peers }\end{array}$ \\
\hline Reward system & $\begin{array}{l}\text { Team rewards } \\
\text { Training }\end{array}$ & $\begin{array}{l}\text { Contribution-related } \\
\text { pay }\end{array}$ & Skill-based pay \\
successfulty in team & $\begin{array}{l}\text { Training in the } \\
\text { performance skills } \\
\text { including general } \\
\text { knowledge of the } \\
\text { production process for } \\
\text { the laboratory } \\
\text { directory }\end{array}$ & $\begin{array}{l}\text { Systematic training in } \\
\text { the performance } \\
\text { managernent skils for } \\
\text { heads of departments }\end{array}$ \\
\hline
\end{tabular}

\section{Performance Management, Power and Control}

Based on some of the themes identified, some of the issues associated with management power and control over work, including removal of ownership of work and work standards from employees, are explored. Moreover, it investigates the performance management issues correlated with creating an environment of inspection and its justification in the pursuit of achieving organisational objectives. Therefore, it is recommended that the organisations using performance management process need to concentrate on creating a learning and developing culture (Bratton and Gold, 1999); and for an approach to be meaningful and worthwhile, elhical principles need to be built into the process (Winstanley and StuartSmith, 1996).

Power and control as parts of political reality are common events; instead, they are considered as normal and usual aspects in management practice (Brooks 1999). In Hatch's (1997) opinion, using power can involve the use of coercion (the threat of force), rewards (control of material resources desired by the subject), norms (the legitimacy bestowed by cultural assumptions and values), and knowledge (control of unique and needed information). Regarding performance management, in Townley's opinion (1993 cited in Armstrong and Baron, 1998). power is implemented through its connection with knowledge, such as techniques of registration-mechanism for the supervision and administration of individual and groups. Moreover, Winstanley and Stuart-Smith (1996) state the existing performance management approaches generally are often perceived as forms of control that are inappropriately used to police performance. Controlling through specification of contracts (performance objectives and measures) and checking to ensure that performance meets that required performance evaluation places performance 
management at the centre of the process for controlling the labour process. The first part of the assignment provides the examples of this issue. Controlling through specification of contracts may occur in planning performance stage. As it is described, the pharmaceutical firm has an organisational objective to design new products for the mass drug market. This is the basis of the performance of research scientists in the research laboratory. Both the laboratory director and research scientists then identify the department objectives, the individual performance objectives, and the essential competence. Next, checking to ensure that performance meets may take palace in formal assessment and reward stage. As $t$ is described, customer and service manager, and costumers in each local area then assess sales representatives' performance on both individual and teambased, once a year in particular months by using Behaviourally Anchored Rating Scales (BARS).

Power and control issues in performance and management may remove ownership of work and work standards from employees. Winstanley and Stuart-Smith (1996) mention it may not be possible for all parties to agree on how performance management process should operate and what performance measures would be appropriate. This may encourage some mechanisms required to ensure that only the voice of power holders is heard. Appraisal, therefore, is a bureaucratic process to which managers are hostile (Stiles et al, 1997). In the example from the pharmaceutical firm, the laboratory director who perceives the real goal as satisfying budgetary or financial targets might give low priority for individual values, for example flexibility. This may cause resentment among the research scientists, as well as anxiety about their continuing employment, given that performance management no longer equates with ownership of work. Moreover, controlling and checking may remove ownership of work and work standards from employees since the evidence suggests that employees are largely disenchanted in terms of the fairness and accuracy of the performance management systems (Stiles et al 1997). th the case of the vacuum cleaner company, the sales representatives may have question marks over the achievability of targets and perceive variability and inconsistency in appraisal. The result is employee passivity and, in some cases, turnover.

In term of creating an environment of inspection and its justification in the pursuit of achieving organisational objectives, The Foucaultian perspective links increased use of performance appraisal to dificulties in conventional supervision and monitoring of employees who perform work roles largely out of sight of their line managers. It uses the analogy of a type of prison design. The guards (line managers) can view prisoners but those incarcerated (employees) cannot see their captors - to demonstrate the surveillance power of contemporary performance appraisal methods (Townley, 1992 cited in Simmons, 2002). In the case of at the large university, precise specification of required the lecturers attitudes, behaviour, performance objectives, and their contingent rewards enables lecturers' objectives vertically integrated with the university strategy so that performance appraisal philosophy and practice derives from, and contributes to, the university's business objectives.

However, since 1991, performance management has been developing some issues such as from annual appraisal to continuous review, system to process, top down to joint review (Armstrong and Baron, 1998). Bratton and Gold (1999, p. 219) moreover indicate the challenge is to achieve "an accommodation of the values of control combined with values which argue for the development of people and the gaining of employee commitment and trust". For instance, in the case of the pharmaceutical firm, the performance management process is designed to reconcile the organisational concerns for control and compliance with the research scientists' expectations of professional development and personal aspirations. Therefore, the criticisms have yielded positive benefits. As Bach (2000) mentions "this has allowed much greater 
clarity in designing and implementing performance appraisal with an explicit consideration of the primary purpose of appraisal; recognizing differences hierarchical or peer-oriented approaches and reward or developmentally oriented systems".

The organisatlons using performance management process then need to concentrate on creating learning and developing culture; and a more othical approach to performance management could take place. As Bratton and Gold (1999) state creating a leaming and developing culture is recommended so that appraisal to be accepted by employees as a means of tying the satisfaction of their needs and their development to the oblectives of the organisations. Armstrong and Baron (1998) mention performance and development reviews, whether conducted formally or informally, can be regarded as learning events, for example learning opportunities for the sales representatives to improve teamwork skills are provided before, during. and after formal meetings. Moreover, Winstanley and Stuart-Smith (1996) propose four ethical principles need to be built into performance management process: respect for the individual, mutual respect, procedural fairness, and transparency of decision making. Based on the part one of the assignment, the first ethical point concerns respect for the individual and giving equal opportunitles to all stakeholders in the organisations that is needed, for example, when defining the individual objectives. The second one is the requirement for a shift away from seeing the organisations as purely economic constructions to serve the profit motive, and towards viewing them as communities of interests, which may sometimes conflict. This is important, for instance, when identifying the development plans. Furthermore, where genuinely different Interests exist, it suggests that the ethical concept of procedural fairness is relevant, such as by eliminating problems and pitfalls of the appraisal methods. Flnally, staffs affected by decisions, for example reward system, should have the opportunity to scrutinise the basis on which the decisions were made.

in conclusion, for performance management to be valuable as HRM strategy, the focal point has to move away from measurement and control towards developing learning and developing culture to allow sustainable improvements take place. The other point is ethical principles built into performance management process that increase understanding and build up trust:

\section{Bibllography}

Amstrong, M, 2002. Employse reward. London: CPD.

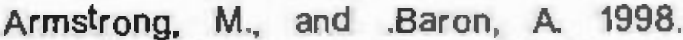
Performance management: the new. realities. London: CIPD.

Armstrong, $\mathrm{M}_{\text {, }}$ and Baron, A 2005. Managing performance: performance management in action. London: CiPD.

Bach, S. 2000. From Performance Appraisal to Performance Management in $S$ Bach and K.Sisson, Personnel Management: A Comprehensive Guide to Theory and Practice, Oxford: Blackwell.

Bartol, K.M. 1999. Reframing salesforce compensation systems: An agency theory-based performance management perspective. The Joumal of Personal Selling \& Salos Management. Vol.19, Iss. 3, pg. 1-16. O n I i ne. A va i I a b I e : hitp://proquest.umi.com/pqdweb?did= $45346423 \&$ sid $=24 \& \mathrm{Fm}=4 \&$ clientld $=4$ 8146\&RQT $=309 \&$ VName=PQD [10 November, 20055]

Beardwell, i, and Holden, L. 2001. Human Resource Management. A contemporary approach. Third edition. Essex, Pearson Education Ltd. 
Blyth,A. 2005. Spirit's guide to designing your own HR management tools. Personnel Today. Online. Avallable: http://www.personneltoday.com/Articl es/2005/02/22/28122/Splrit's +guide+t o+deslgning+your+own+HR+manage ment+tools.htm [4 November, 2005]

Bratton, J., and Gold, J. 1999. Human resource management: theory and practice. $2^{\text {nd }}$ sedition. Basingstoke: Macmillan

Brooks, I 1999. Organisational Behaviour: individuals, groups, and the organisation, London, Financial Times Management.

Brown, D. 2002. HR must ensure individual goals are met. Canadian HR Reporter. Vol.15, Iss. 4; pg. 7. Online.Available: ht:p://proquest.umi.com/pqdweb?did= 110215479 \& sid $=9 \& \mathrm{Fmt}=4$ \& clientld $=4$ 8146\&RQT $=3098$ VName=PQD [2 November, 2005]

Castka, P, Bamber, C.J., Sharp, J.M., and Belohoubek, J. 2001. Factors affecting successful implementation of high performance teams. Team Performance Management. Vol.7, Iss. 7/8; pg. 123-134. Online. Avaliable: http://proquest.uml.com/pqdink?did= 270070061 \&sid $=6 \& \mathrm{~F} \mathrm{mt}=4 \&$ clientld $=4$ $8146 \&$ RQT $=309 \&$ VName $=P Q D \quad[4$ November, 2005]

ClPD. 2005. Performance Management. Survey report September 2005. O n I i n e. A v a i I a b | e : http://www.cipd.co.uk/NR/rdonlyres/0 7 BC 1 B 7 0-E8 2A-455 D-94 F6AEEE3DEE0D4D/0/perfmansro905.p df [2 November, 2005]

Clark, G. 1999. Performance Management Strategies in Mabey, Christopher., Salaman, Graeme., and Storey, John. Human resource management : a strategic introduction. Oxford: Blackwell Business.
Dessler, G. 2005. Human resource management . 10th ed. New Jersey: Prentice Hall/Pearson Education International

Hatch, M. 1997. Organisational Theory; Modern, symbolic and Post-modern Perspectives, Oxford, Oxford University Press.

Hendry, C., Bradley, P, and Perkins, S. 1997. Missed a motivator? People Management. Vol.3, Iss. 10; pg. 2024. Online. Available: http://proquest.umi.com/pqdweb?did= 12419640 \& sid $=1$ \& F mt $=4$ \&lientld $=481$ $46 \& R Q T=309 \& V$ Name $=P Q D \quad[2$ November, 2005]

Kessler, I. 2000. Renumeration System in S Bach and K.Sisson, Personnel Management: A Comprehensive Guide to Theory and Practice, Oxford: Blackwell.

Mabey, C., Salaman, G., and Storey, J. 1999. Human resource management : a strategic introduction. Oxford: Blackwell Business.

Personnel Today, 2004. Research: Porformance Management. Online. A $v$ a i l a b l e : http://www.personnelloday.com/Articl es/2004/03/02/22806/Research+Perf ormance+Management +.htm [4 November, 2005]

Personnel Today. 2005. Top job: Jacqui Macdonald, HR business partner, AstraZeneca. Online. Available: http://www.personneltoday.com/Articl es/2005/09/13/31568/Top+job+Jacqui +Macdonald + HR+business+partner, +AstraZeneca.htm [4 November. 2005]

Riggio, R.E. 2003. introduction to Industrial'organtsational psychology.

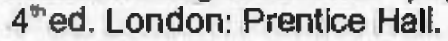


Rodgers, K 2005. Stepping up performance management. Online. Available:http:/ $/$ www.personneltoday. com/Articles/2005/06/07/30188/Stepp ing+up+performance+management.h ton [4 November, 2005]

Simmons, J. 2002. An "expert witness" perspective on performance appraisal in universities and colleges. Employee Relations. Vol.24, Iss. 1/2; pg. 86-100. O n I i ne. A vailable: http://proquest.umi.com/pqdweb?did= $186651351 \&$ sid $=4 \& \mathrm{Fmt}=3 \&$ clientld $=4$ 8146\&RQT=309\&VName=PQD [10 November, 20055]

Stiles, P., Gratton, L., Truss, C., Hope-Hailey, V., and McGovern, P. 1997. Performance management and the psychological contract. Human Resource Management Journal, Vol.7, iss. 1; pg. 57-66. Online. Available: http://proquest.umi.com/pqdweb?did= $12572805 \&$ sid $=18 \mathrm{Fmt}=4 \&$ clientld $=48$ $146 \& R Q T=309 \& \vee$ Name $=P Q D$ [accessed 2 November, 2005]
Thornhill, A., Lewis, $P$, Millmore, M. and Saunders, M. 1998. Managing change: a human resource strategy approach. London: Financial Times

Torrington, D, Hall, L, and Taylor, S. 2004. Human Resource Management. $6^{\text {h }}$ edition. Harlow: Financial Times Prentice Hall

University of Virginia. 2005. Performance Management Model. Online. A $v$ a i l a b 1 e : http://www. virg inia edu/odt/rewsuper visor/performance_management_mo del.htm [4 November, 2005]

Wirstanley, D, and Stuart-Smith, K. 1996. Poficing performance: the ethics of performance management. Personnel Review. Vol.25, Iss. 8; pg. 86. Online. A $\vee$ a $i$ । a b I e : hitp://proquest.umi.com/pqdweb?did= $116360172 \&$ sid $=2 \& \mathrm{Fmt}=3 \&$ client $l \mathrm{~d}=4$ $8146 \& R Q T=309 \&$ VName $=P Q D \quad[14$ November, 2005] 